\title{
CULTURAL CAPITAL, LIFE COURSE PERSPECTIVES AND WESTERN FRONT BATTLEFIELD TOURS
}

\section{Peter Clarke *}

* Griffith Business School, Department of Marketing Griffith University, Nathan campus, Brisbane, Australia.

\section{Anne Eastgate $\dagger$}

† School of Management, University of South Australia, City West Campus, Adelaide Australia

\begin{abstract}
This paper argues that battlefield tours have strong religious overtones covering remembrance and sacrifice that features non-spiritual philosophies built on emotional and cultural capital. This paper canvasses views of tourism, icons, memorials and cemeteries as contributors to cultural capital. There is a view that religion and pilgrimages follow the Life Course Perspectives of religious influences on individual life stories, events and interactions. The proposition suggests that suggest religion meets commemoration. Insights from a group of 28 visitors to the Western Front in 2008 contribute to, and support the tenets of this paper. The Western Front is a single icon built on the cultural elements of emotion, earthiness and respect rather than destination sophistication. Tourists felt the region had not succumbed to excessive or unwarranted infrastructure development that would spoil the experience. Tour party participants considered the tour to be a pilgrimage enabling the achievement of longheld personal goals, create their own memories and heritage to compliment their family history. Ultimately, in the beliefs of Australian tourists to the Western Front, religion does meet commemoration and connects with Life Course Perspectives influences and values.
\end{abstract}

Keywords

Cultural Capital, Life Course Perspectives, Religion, Commemoration, Memorials.

\section{Paper type}

Research paper

\section{Address all Correspondence to:}

Dr. Peter Clarke

Email: p.clarke@griffith.edu.au 


\section{Cultural Capital, Religion, Commemoration, Sustainability and Western Front Battlefield Tours}

\section{Introduction}

Australians come to the Western Front because the Great War was a nation building event that touches most Australians, irrespective of cultural backgrounds (Inglis, 1998). The Western Front is fast becoming a rite of passage for Australians, both young and old (Scates, 2007). In essence, today's tourist comes to a fearful place just as "they" did before them and the accompanying beliefs emerge through an amalgam of cultural capital that is consistent with a religious-style commitment of respect for ancestors and those involved in the conflict.

The Armistice Day (1918) accords on the Western Front meant combatants from both sides occupied the battle areas of the Western Front. Consequently, these soldiers were immediately free to travel as tourists (Ekins, 1998) or revisit the now peaceful battle sites to reflect on the conflict and pay homage to fallen comrades (Lloyd, 1998). The Western Front was a shattered landscape where early tourists came to identify ,view and emotionally link to places of death, defence and victory. In less than a decade, the Somme, and Flanders fields lost most traces of the battles in a return to residential and agricultural purposes (Scates, 2007). The tourists now visit memorials, graves or locations of interest and bring their emotions, values, and gaze upon the settled, serviced rural landscape of the Western Front. Generally, the Western Front is of regional and rural habitation that survives with a minimum of infrastructure services that are in tandem with historical battle sites of World War 1 , the attendant museums and hospitality provisions. Tourists to these sites bring education, knowledge, emotions, values, and family history. Such cultural capital is, by nature, international because these were nationalistic conflicts resulting in dedication to the fallen.

Although the First World War is now beyond living memory, it continues to be a strong fascination of modern British, Australian, Canadian, American and South African imaginations (Lloyd, 1998, Williams, 1994). Three hundred thousand Australians went to The Great War; over 60,000 Australians lost their lives and 120,000 wounded (McQueen, 2004, Lloyd, 1998). They were buried, if at all, not far from where they fell. Pilgrimages to these sites, and the graves of their loved ones, began in the 1920s when mothers, fathers, wives, and children went to Europe on a long, difficult, and extremely expensive journey (Scates, 2007), yet, this distance from 
the battlefields helped define grief as a shared experience (Ziino, 2007). To many who now undertake travel to these sites, the visit becomes a pilgrimage, as these tours are important for Australians and their quest for self-fulfillment (Lloyd, 1998). The following paragraphs allow insights into the characteristics of cultural capital and a selective précis of religion, The Life Course Perspectives (LCP) (Hutchison, 2003) and a discussion relating to icons, memorials and cemeteries suggest that tours of this nature accrue attributes of a pilgrimage. The discussion addresses the proposition that Western Front battlefield commemoration meets religion as these places are sacred, symbolic places that hold secular meaning, attract reverence and are an essential part of these tourists' lives. Later discussions relating to sustainability draws on the literature to demonstrate that Battlefield tourism and the Western Front are also sustainable tourist destinations.

\section{Cultural Capital}

Culture is an expression of group or collective aspects of people's behaviour that cover moral, ethical and religious overtones, as well as aesthetic, social, symbolic and historical values (Throsby, 1999). Generally, cultural capital is intangible, renewable after use and shared with and between others (Diefenbach, 2006). The economic literature refers to the tangible, physical capital of the plant, machines, and buildings that contribute to the production of goods, and, the concept of human capital refers to the embodiment of skills and experiences in the production such goods. All together, renewable and non-renewable resources, ecological processes and natural capital combine to generate income streams through production of consumption goods (Throsby, 1999). Ultimately, natural capital and cultural capital are two interconnected concepts relevant to any discussion about sustainability. Throsby (1999) refers to cultural capital as the management of cultural assets in both tangible (locations, sites and artifacts) and intangible forms such as beliefs and tradition.

Essentially, cultural capital is learned and becomes an asset that contributes to cultural value and an understanding that sustainability, as a cultural ecosystem, underpins the real economy. However, cultural systems may breakdown and affect the way people behave and any choices they make may result in welfare loss and lower economic output (Throsby, 1999). Ultimately, tourism integrates into living, sustainable systems and contributes to the quality of life for tourists, tourism communities and all interdependent stakeholders (Jamrozy, 2007). 
There is evidence of Byrd's (2007) stakeholder contributions theory in the development of the Western Front. It appears future expectations are of rejuvenation through development and infrastructure provision that involves foreign and French governments, land holders, service providers and business operators. The French ceded, in perpetuity, the cemetery and memorial sites to those allied and commonwealth countries involved in the battles. This gesture also includes dedicated German cemeteries that complement and reflect an emotional balance of the conflict. Both Diefenbach (2006) and Throsby (1999) indicate that the available resource infrastructure supports the intangible and tangible aspects of cultural capital. Specifically, Throsby (1999) refers to the maintenance of museums and artwork as a part of cultural capital.

Each country pursues their own goals when they responded to the commemoration of the conflict by erection and maintenance of specific memorials and cemeteries. As a way of improving the tangible assets, the Australian government plans to fulfill a four year programme for an integrated Anzac trail of commemoration on the Western Front (Griffin, 2009). These projects will release the pressure on Gallipoli from overattendance, and the Western Front will receive the attention that this theatre of war deserves in the Anzac legend. Overall, cultural capital draws on religious overtones and aesthetic, social, symbolic or historical values because it is renewable after use and shared with and between others. The next section suggests similar attributes accrue to religion and commemoration.

\section{Religion and Life Course Perspectives}

Hodge (2005) refers to Religion as an internal, subjective reality of rituals, beliefs, and practices that develop in conjunction with other individuals who share similar experiences. On the other hand, secular religion is a term used to describe ideas, theories or philosophies which involve no spiritual component, yet possess qualities similar to those of a religion. Consequently, the sacredness of any secular religion incorporates meaning and purpose to many people and such characteristics become evident in the quasi-religious or civil religious style of Anzac culture (Cranitch, 2008, Lloyd, 1998). The Australian War Memorial (AWM) plays a major role in commemorating and furthering the understanding of Australia's role in various conflicts; there is also a spectrum of special interest publications, films, featured television documentaries and news items. Such publications invoke and reinforce a 
culture of remembrance and commemoration across all generations. For an individual, the ultimate, symbolic commitment manifests through battlefields visits. Due to an amalgamation of seeking personal meaning and identity, commemoration, remembrance and beliefs, such tours become pilgrimages (Ziino, 2007).

Lloyd (1998, p220) expects that pilgrims distinguish themselves from tourists in order to stress their special links with the fallen and the war experience. A pilgrimage is a sacred journey and a search or quest for the pursuit of the ideal. To many pilgrims, these journeys are a mission of great moral significance to a sacred place or a significant shrine. Coleman (2002) argues, pilgrimages are both historically and culturally specific instances that encompass the person, place and story such as the meanings behind collective journeying by Vietnam Veterans’ motorcycle clubs. Soldier pilgrimages began to perpetuate the memory, but these acts of private pilgrimages rapidly transformed into the official fabric of commemoration (Scates, 2007). Today, the Somme and Ypres Salient continue to grow as tourist attractions and is a specialized niche of the tourist and leisure industry (Iles, 2008).

A successful pilgrimage depends on realistic, resourceful, and totally committed leadership (Scates, 2007) where the leadership of these tour activities tends toward retired military officers and published historians. According to Iles (2008), having an interest in family history influences the decision to tour the Western Front. By retracing their ancestors' movements across the battlefield terrain, tourists attempt to reinforce their sense of family pride. These tourists seek meaning, purpose and affirmation of their own self-identity as described in Hutchinson's (2003) later life phase. Life Course Perspectives (Hutchison, 2003) (LCP) chart the influences of religion on individual life stories, events and person-environment transactions within life course concepts. Overall, key themes are personal direction, connectedness and goal fulfillment. While young adults tend towards attaining a sense of meaning, purpose and personal direction, middle adulthood seeks connectedness within a multigenerational family context. In later life, there is a search for personal meaning through reminiscences, self image and accomplishments. In all, there is a retreat to a safe place seeking self-integrity and goal fulfillment (Hutchison, 2003).

\section{Icons, Memorials and Cemeteries}


Religion and LCP address an internal, emotional satisfaction; however, there is a major role and influence due to the presence of icons, memorials and cemeteries. In essence, graves are a tangible reference for private grief: however, the creation of mass and uniform sites meant graves and cemeteries became nationalistic rather than sites of personal grief (Ziino, 2007).

Generally, an icon is an artifact that holds attributes, incurs important experiences (Becken, 2005) and represents a set of mental associations of time, place and cultural links within an immediate environment (Laverick \& Johnston, 1997). All forms of media report and reproduce images and these activities make icons instantly recognizable and become important and enduring symbols of sacredness (Becken, 2005). Traditionally, the word icon refers to art works depicting a religious image, representation, or picture of a sacred or sanctified Christian personage (Sternberg, 1999) and such art takes many forms that include friezes, bronzes, marble, metal, art and glass works (Robb, 2002, 215). Another view treats an icon as a human figure whose gesture, body position, costume and surrounding objects refer to a concept, usually a human virtue or failing, like love, faith, truth, veracity, melancholy, good fortune or greed (Sternberg, 1999). Coleman (2002) indicates that revered images occur within a given space and evoke invisible auras, appeals and desires from a spiritual world.

As Robb (2002) argues, the society of the WW1 period believed each and every serviceman accrued an heroic aura, if not an iconic status, because World War 1 was a divine plan that transferred a war of national interest to a holy war. Specific battles as Zonnebeke and Passchendaele came to acquire an almost sacred ring and thus, became ordained with holiness (Dyer, 2001). In a sense, battle sites, graves and memorials that began as profane sites, emerged as symbolic, sacred places (Lloyd, 1998). Such specific iconic images and sentiment suggest battlefield tours are more than tourist experiences; they become secular pilgrimages.

The narratives of Christian idealism and self-sacrifice feature on monuments (Robb, 2002) where the helping of mates theme is obvious in the Australia Cobbers memorial at Fromelles (Hutchinson, 2006). Many memorials feature patriotism, triumphalism and passages from the Bible to the extent that the civilian and military communities made saints of dead soldiers and shrines of their graves and monuments (Robb, 2002). As such, shrines convert assumptions and hopes into sacralized forms readily 
acknowledged and suitable for easy consumption (Coleman, 2002). Consequently, these physical monuments encourage those simple, yet iconic and symbolic practices of laying wreaths and incantation of the Ode of Remembrance (Pounds, 1998). In earlier times, most British and dominion citizens saw the battlefields of France as holy sites where travelers negotiated the environs of the Western Front to visit ground made sacred by the blood of men (Robb, 2002). The momentous nature of the battles of the Western Front created unparalleled devastation. Although the sites still exist, they are memorials, military cemeteries and museums; or the fields reverted to crop cultivation, rural pursuits, urban development and daily existence (Iles, 2008). Urry (1990) describes tourist behaviour as an activity that is primarily carried out through the medium of vision or the gaze. The modern Western Front panoramas belie the horror and turmoil of battle. While some sites such as Lochagner Crater are preserved, others such as the Canadian trench system at Vimy Ridge underwent restoration, modernization and sanitization for visitors' protection, convenience and easy consumption.

A 'war memorial' is a commemorative object that is either classic or utilitarian in nature and can range from simple memorial plaques, honour rolls and cemeteries to museums and monuments or swimming pools, hospitals and universities (Dyer, 2001). The Australian War Memorial emerged as a national cathedral to commemorate the nationalistic spirit that grew from the deeply moving Gallipoli story of celebrated heroism and defeat in the distant service of an incompetent superior (Galligan, Roberts \& Trifiletti, 2001). Such structures allowed the bereaved to come to terms with war and help sustain faith, beliefs and emotions that remind following generations of the death and sacrifice of the Great War. One aspect of the tourism literature is thanatourism where tourists visit killing sites or battle sites, cemeteries and memorials to the dead (Slade, 2003). While Australians visit Anzac battlefields because they have feelings toward the dead and their feat of arms, they come to these places because the defining, nation building stories happened at Gallipoli, The Western Front and The Middle East (Slade, 2003). Nation building resides in the concepts of cultural capital and tourism sustainability. The graves and memorials of World War 1 are very real sites at which Australians encounter their own beliefs of a tragedy distanced by time and opportunity (Ziino, 2007). Ultimately, shrines or sites are symbolic capital that imparts a certain kind of authoritative value, a sense that 
they can both reflect and affect aspects of people's lives (Coleman, 2002). Rather than merely seeing or gazing, many come for the experience because their imaginations and emotions allow visitors to construct both an emphatic and historical connection with the present landscape (Iles, 2008) that shapes the relationship of present Australians to the past (Ziino, 2007). Thus, the visit becomes an epiphany moment of emotion and cultural capital.

\section{Religion meets Commemoration}

Hodge (2001) provides a qualitative research framework for spirituality and connectedness to the Ultimate ( $p$ 208). The framework consists of consumer behaviour elements that encompass communication, cognition, affect and such elements relate to Life Course Perspectives of Hutchinson (2003). Many tourists come well-prepared with specific battlefield maps and summaries, the service records of their relatives and a working knowledge of the area's history. Understandably, emotions move from disbelief and sorrow to pride, fulfillment and concomitant behaviors range from silence and introspection to positive, expressive actions such as speeches and story-telling. In most instances, a tourist's communication reflects their knowledge utility and emotions about the battlesites.

Battlefield tourism terminology has a religious intent and sacred obligations (Ziino, 2007). As examples, memorial sites and cemeteries are consecrated ground (Lloyd, 1998 p 189) and visitors "gather" in a similar manner to a congregation that gathers for a service. There are prayer offerings, singing of hymns and a solemnity of praise, thanks and reverence for the soldiers, while placing of wreaths and flowers constitute gifts or tokens of appeasement (Mauss, 1969). Other terms relate to western beliefs as soldiers endured a baptism of fire; the battles became a test of personal strength, of manhood and incorporated a rite of passage (Lloyd, 1998). As in mortal toil, the combatants endured hardship and privation while the honoured dead rest in peace and serenity. Ultimately, those who remain unidentified are "Known only to God" and in this manner, most of the religious writing during World War 1 equated soldiers' deaths with Christ's sacrifice (Robb, 2002). This view still resonates today as soldiers gave their lives to save others, which is a common phrase in citations or medal awards and in church services on anniversary days. In addition, the rebuilding and restoration of centuries old churches destroyed in the war represents a supremacy of higher order 
beliefs with churches as a central, if not mandatory feature of battlefield tours and become destinations in their own right (Thurnell-Read, 2009).

\section{Sustainability and Western Front Battlefields}

Byrd (2007) argues that whilst there is no universally accepted definition of sustainable tourism development, a consensus accepts that sustainability is the development of an area where present use of resources does not adversely affect future use of resources. The exploration of cultural capital, religion and Life Course Perspectives suggest Battlefield tourism is an emotional and cultural activity. As such, these attributes are key issues in sustainability. Thus, battlefield tourism is not only of a religious nature but a sustainable tourism activity. The principle of intergenerational equity means culture inherited from forebears passes to future generations (Throsby, 1999, Jamrozy, 2007). Achievement of such goals comes from the collaboration between four distinct stakeholder groups which are the present tourist, the present host community, the future tourist and the future host community. To this end, there is a balance of power between all stakeholder groups to accept responsibility for the development of tourism within their community. This approach suggests that tourism becomes an economic activity rather than a living system (Jamrozy, 2007). Such economic integration reflects the involvement, exploration and development stages of Butler's (1980) Destination Life Cycle. Within a Destination Life Cycle concept, competition between destinations generally intensifies and there is a need to develop some form of sustainable competitive advantage through a selective, targeted approach (Medway \& Warnaby, 2008). This appears as a view suited to hedonic resort pursuits and associated entertainment provision. However, within the Rejuvenation options of the Destination Life Cycle, the Western Front area returned to its former level of economic activity of rural village life and thus becomes natural capital of resources, ecosystem and biodiversity that generates income through production of food and consumption goods (Throsby, 1999).

The historical-cultural heritage of such landscapes needs protection as it is a means to understand the remains of past events, how military actions and activities influenced the features, and the current use of the surrounding landscape (Bulcao, Ribeiro, Arsenio, \& Abreu, 2004). Because of the inhospitable nature and size of the area, Gallipoli inherits a problem with overcrowding, vehicle and pedestrian access 
difficulties and no accommodation. This need for access infrastructure is ongoing and detrimental to, or destroying the physical character of the Gallipoli peninsula. Unlike Gallipoli, the Western Front is village and regional town centric covering thousands of hectares and serviced by roads that existed before World War 1 . The literature concerning Destination Life Cycle lacks reference to the important marketing tool of promotion as a regeneration agent for a destination. Promotion, imagination or emotion stems from cultural values and will not destroy the experience of the Western Front and the associated panoramas. In addition, Urry (1980) describes tourist behaviour as an activity carried out through the medium of vision or the gaze. There are only locations, some preserved or modified battlesites, memorials and museums which mean that the gaze concept is intrinsically linked because imagination, emotion and reverence are the key issues of a battlefield visit.

\section{Method and Results}

A tour to the Somme Battlefields in November 2008 consisted of two buses carrying 80 guests and additional tour managers. Maintaining contact with the other bus proved difficult and a small, non-random sample of 23 responses ensued. The survey structure was a series of Likert-style responses to questions adapted from the literature and opportunities for the tourists to offer their own views. Whilst the use of a hardcopy survey format allowed responses to specific questions, there was an added input of an ethnographic exploration because one author participated in the tour. Consequently, there were numerous, continual opportunities to talk openly about the tour, expectations and feelings in general. Importantly, such information, feelings and thoughts related to life goals, past memories, family stories and anecdotes were shared with others. The scale data reduced to yes and no responses and the analysis was via response counts and reporting of expressions or opinions.

\section{Results}

There were roughly twice as many males as there were females on the Western Front tour; six people born between 1929 and 1939, eight born between 1941 and 1951 and another eight born between 1951 and 1956. These ages are representative of the overall tour cohort. Twelve respondents reported having relatives who served in WW1. Whilst one guest was new to WW1 interests, the longest term of interest was 70 years and the average was just under 30 years. 
There is an emphatic connection with the land (24 positive responses) and consequently, sustainability within rural regional style development rated highly in the tour guests' reactions. On the other hand, some museums and collections lacked sophistication, but still offered a country feel in their presentation. While fifteen considered accommodation was adequate, six thought negatively about the tourist infrastructure. As one guest commented, "after all, we are in provincial France, what else do you expect? - enjoy the experience”. Importantly, twenty-one tourists felt that the rural setting was the essence of the battle sites and delighted to see the region had not succumbed to excessive or unwarranted infrastructure development. Other similar comments expressed happiness that there was not a hamburger stall on each corner and another thought that an increase in commercial infrastructure would spoil the experience.

All in all, the tour party appreciated the memorials, monuments and museums as sources of reverence and learning while the infrastructure provisions of the rural environment were in keeping with the overall serenity and pictographic nature of the area. Ultimately, the tourists considered the battlefields and the Western Front as a single icon that is built on sustainable elements of emotion, earthiness and respect rather destination sophistication.

In regards to the promotional effort, eighteen tour members acknowledged there is a profusion of literary effort available that cover strategies, personnel and biographies as well as pictorial publications. In turn, 22 respondents agreed this output complimented the excellent promotional activity of news broadcasts and public relations style media for the Western Front. Overall, there was general agreement that the Australian government helps to maintain the memory (21), a dignity and purpose (19) and contributes to the profile of the Western Front and the Anzac story (18). The role of government, either Australian, French, German, Turkish or others contributes to the concept of nation building and cross-nation affiliations. Similarly, private enterprise such as tour companies, hospitality and other business compliment the concept of nation building activities. Promotion and nation building come together with traditions because 19 people felt that a visit to Gallipoli is a right of passage for younger visitors and twenty one people felt a visit to the Western Front is for a mature visitor. 
All members agreed that it would be beneficial for Australian culture; Australians should visit The Western Front, because it is a part of nation building, beliefs and traditions. The guests felt the tour enabled achievement of a long-held personal goal (16). Twenty tourists held goals to visit heritage sites, to immerse in AIF Actions (17) and to build their own memories (19). While 21 members thought the story of Anzac and The Western Front was relevant to them, they considered the tour as part of their own, personal and family history as well as heritage. Overall, fifteen members considered that the Anzac story is relevant to them and 19 believed that the Anzac story and the Western Front is symbolic of themselves, their attitudes and is an important part of their life. Since life changes (Hutchison, 2003) move from seeking connectedness in middle adulthood to personal meaning and goal fulfillment of later life, it means that battlefield tours are distinctive. In essence, each guest's enjoyment appears related to self-definition and goal attainment.

Cemeteries, memorials and churches as destinations indicate religious overtones encouraging prayer and personal reflection. All members of the tour believe that the Western Front is about commemoration' rather than tourism infrastructure, and is, above all, a spiritual place that brings a sense of peace. Eighteen respondents felt a sense of fellowship with the French and the tour members experienced a reciprocal sentiment at the formal receptions. All members accept that Gallipoli and the Western front are individual icons that are integral to the Anzac story and nation building. Generally, the tour party appreciated being with people who shared interests and experiences as well as enjoying the company of others. The overriding outcome was to tell others about the Western Front experience (18) and recommend a tour of The Western Front to others (21).

Nineteen respondents agreed that the Western Front is a celebration of survival and life, but all agree the battlefields are a celebration of death and sacrifice. In continuing the theme, 20 guests viewed the battlefields as a sacred place and they regarded the motive for their tour as being on a pilgrimage. One respondent's partner discovered six months before the tour that her Great uncle died on the Somme; she joined the tour and both visited his grave. In their own way, these visitors set out on a pilgrimage and conducted a service of remembrance for that Great Uncle and other individuals who served at the Western Front. As the tour progressed, others offered prayers, orations and prepared speeches at personally relevant sites. 


\section{Discussion}

Cultural capital is a combination of tangible assets (locations, sites and artifacts) and intangible forms such as beliefs, emotions and tradition. Ultimately, culture is an expression of people's behaviour that cover moral, ethical and religious overtones, or aesthetic, social, symbolic or historical values. These tangible and intangible forms come together in battlefield tourism in general and the Western Front in particular.

The date of $11^{\text {th }}$ November 2008 is the $90^{\text {th }}$ anniversary of the signing of the Armistice for the end of World War 1 and the fighting at the Western Front. The sense of anniversary added to the cultural value of the tour and was a focus of the tour purpose. The tour party attended the rededication of the Le Hamel Memorial followed by a Mayoral reception in the town. The town of Peronne also held a Mayoral reception for the tour members. The tour joined in the formal Armistice Day service at the Villers-Bretonneux memorial where one member read a dedication to the fallen. Many of the tour members visited cemeteries where relatives were buried; in most cases, there was a short biography, prayers offered, the ode recited and poppies placed on the grave. These receptions, memorials and dedications meant members exchanged their family stories and the passing-on of these stories over three or four generations reflect the intergenerational equity of cultural capital. Touring these areas meant visitations to museums and since these are destination places of learning or fulfillment, then the journey continues, and sustains, an international, cross cultural learning process because of the destination's location, landmarks and story. Fellowship with the French is cultural capital as are other elements of the Australian Government sponsorship of memory, dignity and purpose. One person presented a family heirloom to the museum at the iconic Victoria School (N'oublions jamais l'Australie - Let Us Never Forget Australia) in Villers-Bretonneux. This gift meant that an emotional gesture not only augmented the museum's holdings but added to the cultural capital that accrues to the museum. The tour members listened to this story and built their knowledge and understanding at a personal level. As the tour progressed, the participants added to their historical notations to create their own social and symbolic stories where their emotions intertwine with their family history and WW1. One obvious promotional activity was the tour company's exclusive, guided tours promotion that appealed to this older adult cohort. 
Members of the tour party came prepared with well researched notes on military units, specific battles and locations. The members realized early in the tour that the military chess game was secondary to the emotional and symbolic elements that constituted the essence of the tour. Consequently, the Western Front continues to grow in stature as both the media and visitors build the story, increase the awareness of the area and generate desire in others to want the experience and visit. Possibly, as more tourists visit, the Western Front will change and encounter similar problems experienced at Gallipoli with landscape degradation due to tourism infrastructure requirements such as roads, parking, hospitality and accommodation. Maybe, with a consensus of all stakeholders, including national governments' interest and cooperative efforts, will avoid such an eventuation. However, in France, there are regulations in place that limits access and scavenging around private property and memorials, consequently, the area retains it character and value as an important pilgrimage destination. Battlefield tourism appears to be sustainable because the visitor does not seek novelty amusements, does not demand participation as such and allows judgments and attitudes based on knowledge and emotion. Any battlefield tour incorporates cultural capital because the inputs are generational and historical while the outputs are emotional, symbolic, social and nation building. For Australians, the battlefields (The Western Front in particular) are sustainable, nation building tourist destinations that exhibit stakeholder contributions theory in the development of the Western Front and cultural capital criteria.

There is strong research in the tourism genre that has a focus on destination life cycles and continuous infrastructure development to expand operations and present points of differentiation. Battlefield tourism may not need a strategy of defined building and attraction activities because the battlefield itself is the attraction. Future research should focus on the elements of cultural research and the contribution to undertaking travel to specific battlefield tours, eco tours or adventure tours. This paper aligns cultural capital with the tourism industry. Future research should investigate the role of cultural capital in everyday consumption decisions and an individual's sustainability values.

The emergent literature and analysis of the Western Front theatres cover tactical summaries, unit histories, logistics analysis, machinery and armour, war generals, combatants' heroics and dedication as well as selections from a myriad of related 
military, service and personal topics. Whilst there are some narrow insights into contemporary culture, there are few insights into cultural and religious inputs and outcomes that maintain the memory through upcoming generations. Locating this study within the Life Course Perspectives (Hutchinson, 2003) helped describe guests' personal views and goals within a religious context.

This paper argues that battlefield tours have strong commemoration and religious overtones and this combination is a powerful tool for continuing remembrance of the sacrifice of many. The length of interest meant the visitors were well informed, held set life expectations and sought a deeper respect, understanding and meaning toward the soldiers, the battles and the enormity of the conflict. Ultimately, the tour members believe that the Western Front is a sacred place that is symbolic of themselves and their attitudes. Importantly, the area holds secular meaning and attracts reverence. Such a view reflects the narratives of Christian idealism and self-sacrifice that appear on monuments and through the sanctity associated with Australian war graves. In due course, service personnel of the era assumed an iconic status and such images and secular sentiment suggest battlefield tours are more than ordinary tourist experiences. If a pilgrimage is about a person, place and story, then tours to Western Front battlefields are pilgrimages because it involves the person, their values and the story is personal, intimate and seeks deeper meaning in line with Life Course Perspectives. Many returned servicemen chose not to talk about their service or battle experiences and the tour guests acknowledged a similar difficulty in explaining their feelings and emotions, in effect, the tour became an epiphany pilgrimage that questioned or confirmed their own values.

\section{Limitations and Future Research}

The research reported here is limited to a small Australian special interest group featuring an older cohort. These people have the time and money available to overcome the financial costs and distance that is still a problem for many Australians. Additional limitations arise because the small number of Australian tour operators generally limits the number of tourists to the Western Front, or any battlefield, therefore, potential research is limited to qualitative interpretations rather than quantitative relationships. A further limitation is access to tour providers as many appear as specialist, low profile tour operators. 
Promotion of Australian military history and World War 1 is the key to a secular belief in the meaning, purpose and beliefs associated with conflicts. Consequently, the religious commemoration connection is particularly strong in the Australian national ethos and other research avenues could address this nexus within each combative country such as Britain, Canada, America and South Africa or dominion countries such as India or Vietnam. On the other hand, German beliefs, culture and commemoration is a worthy avenue of investigation. Future research could address a quantitative approach to the attitudes, beliefs and motivations of Australians to believe in, or, participate in a Battlefield tour to the Western Front or other significant Anzac battleground sites across the world. This research should include the impact of attachment theory with the sites and the anniversary occasion of the tour. There is a possibility that Australian tour groups to other, more recent battleground sites may hold different emotions and attitudes. Since such tourism is a personal goal, there are opportunities to assess the scope of commemoration from a non-traveller perspective and assess if a tour is an epiphanic pilgrimage.

Lest we forget. 


\section{References}

Becken, S. 2005, "The role of tourist icons for sustainable tourism", Journal of Vacation Marketing, Vol. 11, No. (1), pp 21-30.

Bulcao, L., Ribeiro, L., Arsenio, P. and Abreu, M. M. 2004, "The protection of landscape as a resource: Case study - Monte da Guia protected area (Faial-Azores)", Management of Environmental Quality: An International Journal, Vol. 15, No. 1, pp.

Butler, R. W. 1980, "The Concept of a Tourist Area Cycle of Evolution: Implications for Management of Resources." Canadian Geographer, Vol. 24, No., pp 5-12.

Byrd, E. T. 2007, "Stakeholders in sustainable tourism development and their roles: applying stakeholder theory to sustainable tourism development", Tourism Review, Vol. 62, No. 2, pp 6-13.

Coleman, S. 2002, "Do you believe in pilgrimage?: Communitas, contestation and beyond", Anthropological Theory, Vol. Vol. 2, No. No. 3, pp 355-368.

Cranitch, T. 2008, "Anzac a 'Politically Pliable' Legend", Eureka Street [online].. Vol. Volume 18, No. Issue 9, pp 47-48.

Diefenbach, T. 2006, "Intangible resources: a categorial system of knowledge and other intangible assets", Journal of Intellectual Capital, Vol. 7, No. 3, pp 406-420.

Dyer, G. 2001, "The Missing of the Somme", Phoenix Press, London.

Ekins, A. 1998, "The end of the Great War: Australian soldiers and the armistice of November 1918", Wartime, Vol. Summer, No. Issue 4, pp 8-13.

Galligan, B., Roberts, W. and Trifiletti, G. 2001, "Australians and globalisation : the experience of two centuries", Cambridge University Press,, Oakleigh, Vic.

Griffin, The. Hon. Alan. MP. 2009, "\$10 million for Anzac Trail on Western Front", Minister for Veterans’ Affairs, Parliament House, Canberra.

Hodge, D. R. 2001, "Spiritual Assessment: A Review of Major Qualitative Methods and a New Framework for Assessing Spirituality", Social Work, Vol. 46, No. 3, pp 203.

Hodge, D. R. 2005, "Spiritual life maps: a client-centered pictorial instrument for spiritual assessment, planning, and intervention." Social Work, Vol. 50., No. 1 (Jan), pp p.77.

Hutchinson, G. 2006, "Pilgrimage: A traveller's guide to Australian battlefields", Black Inc., Melbourne.

Hutchison, E. D. 2003, "Dimensions of human behavior. The changing life course", Sage Publications, Thousand Oaks, Calif.

Iles, J. 2008, "Encounters in the Fields - Tourism to the Battlefields of the Western Front", Journal of Tourism and Cultural Change, Vol. 6, No. 2, pp $138-154$.

Inglis, K. 1998, "War memorials in the Australian landscape", Wartime, Vol. Summer, No. Issue 4, pp 21-24.

Jamrozy, U. 2007, "Marketing of tourism: a paradigm shift toward sustainability", International Journal of Culture, Tourism and Hospitality Research, Vol. 1, No. 2, pp 117-130. 
Laverick, S. and Johnston, K. 1997, "The marketing of a consumer icon: Mini Cooper into Japan - coals to Newcastle?" Marketing Intelligence \& Planning, Vol. 15, No. 4, pp 179 - 184.

Lloyd, D. W. 1998, "Battlefield tourism : pilgrimage and the commemoration of the Great War in Britain, Australia and Canada, 1919-1939", Berg, Oxford.

Mauss, M. 1969, "The Gift: Forms and Functions of Exchange in Archaic Societies", Cohen and West, London.

McQueen, H. 2004, "Social sketches of Australia, 1888-2001", University of Queensland Press, St. Lucia, Qld.

Medway, D. and Warnaby, G. 2008, "Alternative perspectives on marketing and the place brand", European Journal of Marketing, Vol. 42, No. 5/6, pp 641-653.

Pounds, R. 1998, "The Ode", Wartime, Vol. Summer, No. Issue 4, pp 56-57.

Robb, G. 2002, "British Culture and The First World War", Palgrave Macmillan, Houndmills [England].

Scates, B. 2007, "Soldiers' journeys: returning to the battlefields of the Great War", Journal of the Australian War Memorial, Vol. No.40, February, http://www.awm.gov.au/journal/j40/scates.asp accessed 20/2/2009.

Slade, P. 2003, "Gallipoli thanatourism: The Meaning of ANZAC", Annals of Tourism Research, Vol. 30, No. 4 October, pp 779-794.

Sternberg, E. 1999, "The Economy of Icons: How Business Manufactures Meaning", Praeger,, Westport, CT.

Throsby, D. 1999, "Cultural Capital", Journal of Cultural Economics, Vol. 23, No. 12, pp 3-12.

Thurnell-Read, T. P. 2009, Engaging Auschwitz: an analysis of young travellers' experiences of Holocaust Tourism, Journal of Tourism Consumption and Practice, available http://www.tourismconsumption.org/JTCPV1,1,\%20A002_Thurnell_Read.pdf [Accessed Volume 1, No.1]

Urry, J. 1990, "The Tourist Gaze: Leisure and Travel in Contemporary Societies", Sage, London.

Williams, V. 1994, "Warworks: Women, Photography and the Iconography of War", Virago Press, London.

Ziino, B. 2007, "A Distant Grief: Australians, War Graves and the Great War", University of Western Australia Press, Crawley, WA. 